\title{
Everything seems so settled here: The conceivability of post-Peircean biosemiotics
}

\section{Claudio J. Rodríguez Higuera' ${ }^{1}$}

\begin{abstract}
Theory change is a slow, tortuous process. Problems associated with how we communicate ideas and how these ideas are received by our peers become catalysts for change in how we ourselves perceive and sanction what the discipline is capable of doing. Some parts of semiotics, and particularly biosemiotics, have come under critical scrutiny because of their heavy commitment to Peircean philosophy, but at the same time, the contributions of Peircean philosophy are almost impossible to discount. The ripples of this situation are quite visible in the emergence of code biology as a post-semiotic research programme. Yet there is a general balance between those who do not put that much stock in Peircean concepts and those who cannot conceive semiotics without these.

This paper will ask whether a biosemiotics after Peirce is possible at all in the sense of acknowledging Peirce's contributions to the field while also taking to heart the criticisms raised by those skeptical of the implications of Peircean semiotics. While the answer is most likely positive, it depends on what background our concept of meaning relies on and how it may bleed into the other areas of semiotics that biosemiotics may claim a stake on. Being able to discuss potential theoretical distinctions across semiotics while also allowing communication between the areas caught in this differentiation will be crucial for the health of the discipline as the gap between theories becomes more profound.
\end{abstract}

Keywords: biosemiotics; Peirce; post-Peirceanism; theory change; theoretical pluralism

\section{Introduction}

There is no denying that figureheads carry a lot of weight in representing the ship that is our corner of research. The different projects represented under the banner of semiotics do not necessarily require the same object of study or unit of analysis ${ }^{2}$, and while this disunity could be bridged through a combination of terminological technology and commitment to a specific ontology - a space that biosemiotics has purportedly attempted to occupy (Brier 2015; Cobley 2016), the

1 Department of General Linguistics, Palacký University, Olomouc, Czechia; e-mail: claudiojrodriguezh@gmail.com.

2 Take, for instance, the difference in the text semiotics of the Tartu-Moscow School and the sign-oriented semiotics of Peircean approaches (Lotman 2002). 
task is made more complex due to philosophical and scientific differences between the practices of those who do semiotics.

Biosemiotics, granted, keeps developing as an interesting prospect for a bridge theory for meaning at different levels of complexity, and it offers a strong naturalistic basis for semiotics. This paper will focus on biosemiotic theory and the scrutiny its Peircean bent has undergone in the past few years. The question we are bound to ask, when considering the philosophical differences we just mentioned, is whether there is a possibility for a biosemiotics that takes to heart such criticism without throwing out the baby with the bathwater. A post-Peircean biosemiotics of sorts could perhaps accomplish this, but its own realization remains, I contend, elusive. What I mean by a post-Peircean biosemiotics would then be a biosemiotics that is inclusive of the concepts brought forward by Peirce without a strong dependence on the limits of Peircean metaphysics, triadicity and the rigidity of his semiotics as logical forms. We will make a more fine-grained distinction of what could count as post-Peircean in this view. To be clear, I am not advocating for a removal of Peircean concepts, be those signs, semiosis, categories, etc., but rather, the central issue is how such concepts may put a certain strain on the types of semiotics we can do in the future. Peirce, however odd this may sound, was not a biosemiotician, and so Peircean biosemiotics is not defined as a complete orthodoxy regarding Peircean philosophy, but rather, as a biosemiotics that is based on rigid Peircean concepts. We will talk more about this later.

The leading question we ask certainly depends on the terminological nuances of specific concepts - be those Peircean or parallel to them - and how we take them to work in our theories. That being the case, first we will examine the role of biosemiotics as a base level theory for general semiotics and how this position might be defended, in order to move forward to more specific claims about what Peircean, non-Peircean and post-Peircean biosemiotics may look like. The first issue here lies in the dependence of biosemiotics on Peircean concepts and the problems it has generated both theoretically and institutionally for the discipline.

\section{Peircean biosemiotics}

Instead of presenting an introduction to the tenets of Peircean biosemiotics, ${ }^{3} \mathrm{a}$ more pressing issue to be discussed here relates to how foundational Peircean concepts are for actually doing biosemiotics. My first contention here is that biosemiotics functions as a base-level theory for general semiotics in the sense

3 Some among the many to be mentioned include Vehkavaara 2007; Brier 2008b; Fernández 2014 , etc. 
that conceptually it should retain a more foundational value over other views of what counts as 'semiotic.4 The prevalence of terminology directly tied to Peircean semiotics is an essential part of the biosemiotician's toolbox and one of the reasons why biosemiotics is essentially capable of discussing semiotic issues where reportability is not an option. In extending Uexküll's umwelt theory to include signs as triadic relations from Peirce, biosemiotics (at least the biosemiotics that uses this terminology) becomes inherently focused on making sense of the fact that such signs operate at all biological levels. Owing to Sebeok's work, the Uexküll-Peirce synthesis has become probably the most productive axis of biosemiotic research (Favareau 2008: 27-37). ${ }^{5}$ What cannot be discounted then is that the productivity of the approach is what defines the biosemiotic as semiotic, at least regarding the terminological backbone of the theory.

Signs, being one of the essential parts of semiotic theor $y^{6}$ are generally used in their Peircean variety, the Saussurean alternative deemed less than optimal for application. ${ }^{7}$ There are certainly some reasons for such a development: The problems we avoid by not having to deal with the direct sense of representation in Saussurean signs is one of the most alluring parts of Peircean biosemiotics. Yet having signs in the Peircean sense does not give us free rein to locate them over all potentially semiotic processes, that is, anomalous sets of three elements cannot be accepted as signs unless we have some consistent way of verifying that such sets constitute actual sign relations. ${ }^{8}$ That being the case, triadic signs work at building explanatory bridges for each case where potential sign processes may be found. And while this call for careful application of Peircean concepts only echoes already established concerns (Vehkavaara 2005), the various interpretations of Peirce make for very different lines of argumentation among the supporters of his theories. In that way, Deely's philosophical organon ${ }^{9}$ does not exactly mirror the biosemiotics of Hoffmeyer (2010) or Brier (2017) in the sense that what they take from Peirce is not necessarily aimed at the same end.

\footnotetext{
4 A more precise overview of semiotic thresholds can be found in Rodríguez and Kull 2017.

5 A cursory search for 'Peirce' on the Biosemiotics website as of December 2019 shows 176 results (out of a potential 359), with 'Hoffmeyer' running close at 169 and 'Uexküll' at 167. While this is far from a scientific illustration of the relevance of Peirce for biosemiotics, we can use it as a quick example of proportion of his mentions in the most relevant journal for the field.

6 Although not the only one, and sometimes not even a priority element in some theories.

7 See for instance Chang 2009.

8 Deely's usage of a dinosaur bone as an instance of a virtual relation that gives rise to physiosemiosic theory is, I believe, one such example, strongly criticized by Petrov (2013) and Champagne (2013).

9 As, for instance, in his Four Ages of Understanding (Deely 2001) or in "The semiotic animal" (Deely 2005), to name only a couple of entries in the wealth of his theoretical work.
} 
The rise and strength of the Peircean inclination of biosemiotics, which can be attested to in volumes such as Romanini and Fernández 2014, are a testament to the impact general Peircean semiotics has had on the field as a whole. This is not limited to Peirce's concept of the sign, though. Aside from the sign and its methodological usefulness, there are other elements of Peirce's philosophy that are attractive to some areas of biosemiotics, such as the firstness/secondness/ thirdness triad of categories as ontological support for the concept of the sign in order to argue for the emergence of semiosis (Emmeche 2011; El-Hani et al. 2009) or as a type of phenomenal categorization to explain specific semiotic phenomena (Maran 2016), to name only a couple of notable examples.

The influence of Peirce in biosemiotics is certainly not exhausted there, and examples of different concepts used by semioticians crop up without much trouble. Perhaps, then, the best way to be clear about it lies in stating that, on the whole, a large majority of biosemiotics is conducted within the Peircean framework (Barbieri 2009: 227). One question that arises here is whether using the Peircean concept of the sign implies any sort of commitment to a supporting metaphysics and to Peircean metaphysics in general, as is the case of Deely's theoretical work, where the sign does its intended work as an expression of his interpretation of Peirce's metaphysics (Deely 2001: 634-645).

In general, Peircean biosemiotics is characterized as a commitment to Peircean concepts with some rigidity, such as sign types and categories, as we can see in the work of Hoffmeyer (2008), Deacon (2011), Stjernfelt (2007), Fernández (2014), and so on, and with good reason, as such concepts are profoundly informative of meaning as a multidimensional phenomenon. Divergences in interpretation notwithstanding, the common Peircean ground for mainstream biosemiotics (if there is such a thing) seems clear enough - it is not about being solely committed to Peirce, but to the acceptance of Peircean concepts as the ground for semiotics. In any case, Peircean biosemiotics is not the only way forward, with criticism levied against it on different fronts. In the following section we will discuss what some of these problems are and why committing to Peircean biosemiotics may not necessarily be the best option for talking about meaning in the biological world.

\section{Criticisms against Peircean biosemiotics}

Despite the ample presence of Peirce's conceptual framework within biosemiotics, there are lingering issues related to either the philosophical background of such semiotic assumptions or the prevalent institutionalization of Peirce's concepts across biosemiotics. 


\subsection{Philosophical objections to Peircean biosemiotics}

The first type of objection points to the problems with committing to some of the more complex concepts supporting the triadic sign. Though the sign as a triadic relation is a fairly intuitive way to frame meaning-making across different levels of complexity in organisms, the three categories require a deeper commitment to Peirce's philosophy. One may surmise the interest in going deeper rests in making the concept of the sign sound within a biosemiotic framework. That is, in order to argue for signs as a biological phenomenon, there may be a perceived insufficiency regarding the extent to which they cover the simpler biological forms. That, in turn, may lead to seeking support on the same philosophical mechanisms Peirce described, adopting more or less a wholesale approach to Peircean semiotics as applied to the biological realm.

In the process of adopting the more complex strata of Peirce's philosophy, we may find incompatibilities at the level of metascientific integration and at the level of interpretation. Brier's integration of Peircean philosophy within his biosemiotic theory leads to a large-scale theory ${ }^{10}$, which has been criticized by Sharov (2010, 2016) on a number of items, including the idea of pure feeling and the taking of habits as, one may surmise, either universal laws or law-like properties. This, however, goes against current biology, according to Sharov, because developing habits "requires heredity or long-term memory which has not been found in the physical universe, and feelings require complex heritable sensors which are also not found outside of life and its products" (Sharov 2010: 1052). In this case, then, the implementation of semiotic elements within simpler areas of what could constitute the semiosic world is harder to identify when it comes to sign classification (Sharov 2010: 1058), making vegetative semiosis beyond the realm of Peircean sign concepts.

The idea that sign types cannot be correctly identified when instances of life appear far beyond the threshold of human phenomenal understanding is an objection that should be taken seriously. The immediate response one may muster lies in the logical ground of sign types, making thus the assumption of sign types safer in its application to the vegetative world, for instance, as argued by Kull (2009b: 16), taking these possible sign relations as limited to the iconic and only as a first approach to a model. In other words, appealing to signs as logical forms does not pose the requirement of a central nervous system, but instead makes the instantiation of sign relations dependent on an epistemic discernment about their presence from the side of the semiotician. This in turn becomes a problem on effective $v s$ supposed signs that could constrain the evolutionary concept of semiosis within a Peircean framework (Rodríguez Higuera 2019).

10 Attested to in Brier 2008a. 
Sharov argues that, terminologically speaking, we may be better off using functional information as a pragmatic road between semiotics and cybernetics. Kull, on the other hand, argues that certain biological processes such as adaptation are "qualitative phenomena" to be therefore "seen as iconic relations (or in more complex situations also as indexical or symbolic relations)" (Kull 2009a: 81). Moreover, Kull argues that the logical proposition form of signs as conceived by Peirce does not do justice to at least one qualitative aspect of meaning-making, namely the subjective present of organisms, necessitating signs between the level of complexity of indices and symbols (Kull 2018: 140). Lidov (2019), on the other hand, does not find support for the idea that life and semiosis are coextensive when framed under the concept of Peircean triadicity, questioning one of the foundational claims of the Peirce-Uexküll synthesis.

Something else that seems to be at stake is the possibility of actually applying high-level qualitative concepts to low-level processes, and whether there is value in doing so. Kull et al. (2009: 169) are keen on preserving the sign as the primary unit of analysis of biosemiotic research, and that, in turn, implies understanding the specificity of said signs in biological processes. There are areas of debate here that seem hard to resolve at first. The idea that symbols are more complex and emerge over sign systems in evolution (as for instance in Vehkavaara 2003) is contested by Stjernfelt (2012) on the grounds that the icon-index-symbol triad is not discrete, with no period in evolution limited to a certain type of sign.

Though Sharov's criticism does not point to a complete refutation of sign types, opting instead for an alternative, the takeaway lies in that if we interpret sign types related to interpretation, we may have trouble identifying their direct usage in organisms whose experience seems too far removed from that of organisms with central nervous systems. In a similar vein, Barbieri (2008) believes Peircean semiotics does not tell the full story about what exactly is semiotic in organisms. In his criticism, Barbieri distinguishes between Saussurean and Peircean semiotics not in terms of the number of positions in the sign relation, but rather as focused on external coding in the case of Saussure and internal interpretation in the case of Peirce (Barbieri 2008: 24). This is problematic because, in his view, coding is prior to interpretation, and both aspects should be taken in consideration when giving a fully-fledged model of semiosis. Barbieri's interpretation of the usage of Peirce is a form of criticism insofar as it accounts for a view of semiosis that is limited to a higher level of semantic complexity. This form of using Peircean concepts would limit the biosemiotician's capacity to understand the underlying principles of signification in cases where there is a perceived insufficiency of elements to create meaningful distinctions in organisms. 
In addition to that, Barbieri (2015: 167) sees Peircean concepts as a simple renaming of biological processes without actually generating new knowledge about them. These would cause terminological issues, given that their role as placeholders for other concepts muddles the picture by adding an ad hoc notion of interpretation that looks semiotic, but does no conceptual work. There is something to be said about the accuracy of Barbieri's interpretation of Peirce and whether this criticism is fair towards biosemiotics in general, ${ }^{11}$ but the compatibility of theoretical approaches, between code biology and Peircean semiotics, is not a given, as Vega (2018) has shown in his attempt at a reconciliation between both.

In an extensive review on the limits of Peircean concepts as applied to biosemiotics, Vehkavaara expresses concern about the insufficiency of the concept of the sign on its own, but owing to a strong Peircean background, he sees in Peirce's ethics of terminology a reaffirmation of the concept of the sign throughout its different definitions, taken as different perspectives for the same theoretical object (Vehkavaara 2005: 291). Since the Peircean sign works as an "explanation for the possibility of knowledge" as applied to scientific research through human experience, it becomes restricted in its usage - the object of the triadic relation is potentially problematic when applied beyond the area first foreseen by Peirce. ${ }^{12}$

Two opposite trends of criticism can inform the Peircean constitution of biosemiotics. On the one hand, we can see how the adoption of these concepts can be problematic when dealing with simple organisms, either because of the epistemic barrier between assumed signs and actual signs or because of the assumed incompleteness of the theory to account for actual meaning-making in organisms. On the other hand, if we make use of Peircean semiotics, it may not be enough just to allow our theories to shoehorn signs in without having an adequate philosophical framework for them actually to do the work they are supposed to do.

If we consider the claim that Peircean semiotics cannot truly reflect the semiotic world of organisms without a central nervous system, either because it is not possible to find the phenomenal correspondence between sign types, or because Peircean concepts only reflect one axis of what is necessary for biosemiosis, then (some) biosemiotic theories will depend on making distinctions about what is meaningful for organisms and how, without having to invoke Peircean mechanisms.

11 See, for instance, Champagne 2009.

12 However, Vehkavaara (2005: 292) accepts that the triadic relation itself can be used within a wider scope, although we must remain vigilant about the loose use of the concept. 


\subsection{Institutional objections to Peircean biosemiotics from code biology}

Besides the problems we have just discussed, the perceived encroachment of Peircean semiotics has caused a backlash from those who see this influence as detrimental to the research project of biosemiotics, as particularly (and repeatedly) expressed by Barbieri (2015). The emergence of code biology as a research programme is, one could argue, a direct result of the influence of Peircean terminology over the semiotic description of biological processes. ${ }^{13}$

The institutional problem is laid out in the description of the so-called "Peirce industry" (Barbieri 2015: 168) as a machinery imposing Peircean semiotics as the sole means to do any semiotics whatsoever, including biosemiotics. As part of this criticism comes the proclivity to entertain pseudoscientific language and parallelling anti-scientific thinking in the form of intelligent design (Barbieri 2015: 168). Barbieri's intuition is that biosemiotics should not depend on Peirce in order to be scientifically successful, and that the prevalence of Peircean concepts only takes away from the scientific proposition of biosemiotics. The criterion for what counts as scientific may depend, in this case, on a non-reductive mechanistic approach to biological codes (Barbieri 2015: 16; Beni 2019), and while one may contend the borders of what counts as scientific for semiotics in general and for biosemiotics, the criticism is aimed at certain problematic visions of what semiotics may defend or enable, such as an ultimately dogmatic root for semiotic propositions, as physiosemiosis may be considered in some of its forms. ${ }^{14}$

Barbieri's objection to Peircean biosemiotics being the sole way to do biosemiotics (and the intellectual regression that allegedly comes with it) leads to a formal split (Barbieri 2015: 169) from a number of supporters of this criticism, and, institutionally, this is a relevant move for biosemiotics as a field moving towards consolidation.

The institutional claims should, in our opinion, be taken seriously by semioticians, both those involved with Peircean philosophy and those not completely invested in it, because they already have had a significant formal impact on the institution of biosemiotics. Our position here, however, differs from Barbieri's criticism in considering, first, that code biology still belongs to a wider notion of biosemiotics, and second, that non-Peircean varieties of biosemiotics are viable and effective. In what follows we will focus on a number of positions that do not depend on Peircean semiotics to be valid biosemiotics.

13 We consider code biology as part of biosemiotics, albeit a non-Peircean one. While this approach predates its integration to the biosemiotics paradigm, institutionally speaking, there is, I believe, a clear splintering in the current landscape of semiotics.

14 This issue runs much deeper than can be unentangled in this paper, but I consider Deely (2001b) to be a clear representative of some of the issues hinted at by Barbieri (2015). 


\section{Non-Peircean biosemiotics}

In his scathing institutional criticism, Barbieri (2015: 167-168) mentions that, when consulted, an overwhelming majority of people involved with biosemiotics supported the Peircean approach, and that the role of the so-called Peirce industry made other approaches simply not viable. The doom and gloom that this presupposes is, in our opinion, overstated, as non-Peircean alternatives have been present within the field and accepted as semiotic not because they comply with Peircean concepts, but because they follow the premises of a semiotic biology, that is, trying to understand what sort of knowledge (lato sensu) is biologically produced and induced (Kull 2009a), and how this knowledge becomes meaningful for organisms (Kull et al. 2009). We could contest these principles as being grounded on Peircean premises, resulting thus in a necessarily Peircean programme, because Barbieri's objection to interpretation being carried out solely by internal means of the organism could still hold. Such an objection, however, would be the result both of accepting that biosemiotics is unequivocally a Peircean enterprise, which we do not agree with, and of presupposing that meaning in the semiotic sense does not entail a different type of approach to biological knowledge.

Non-Peircean biosemiotics can be thus described as the type of semiotics generated outside of the Peircean philosophical framework and recognized as bringing knowledge of biology regarding the usage of signs (in simpler or more complex varieties), meaning or a combination of both. While this certainly is too wide a definition to be truly useful, institutionally we can also recognize these as being part of the development of biosemiotics because of their role within other views.

Pattee's pioneering work opens up issues of biosemiotics by arguing for mattersymbol complementarity ${ }^{15}$ without invoking Peircean language, and yet this point is shared by Hoffmeyer (2008), but informed by sources that draw more heavily on Peirce. At the same time, if we accept that code biology still deals with the same general aims of biosemiotics as described earlier, Barbieri's work is another example of the non-Peircean variety of biosemiotics.

Biosemiotics has been historically conceived of as a pluralistic academic endeavour in that it attempts to look past biology. In that respect, it looks for ways to make sense of biological knowledge under the premise that meaning-making must complement our descriptions of biological phenomena. While Peircean semiotics may appear to be synonymous with semiotics in general, the idea of meaning-making in biology does not necessitate specific Peircean terminology in order to be valid. In fact, although Barbieri is most likely not wrong about

15 See, for instance, Pattee 2008. 
the strong identification with such terminology and general philosophical identification, biosemiotics is not only conceived of through Peirce. The Uexküllian background of the discipline and the integration of phenomenology at higher levels of semiotic complexity ${ }^{16}$ have opened up the areas biosemiotics is capable of covering without taking away the relevance of the research on more fundamental aspects of semiosis. Even if not grounded in the same kind of language, the search for the origins of biosemiotic phenomena can be found in influential works of the likes of Rosen (1991) and Kauffmann (1995), and concurrent biosemiotic approaches that see no particular need for Peircean language can be found in Markoš 2002 or in the earlier Kull $1993 .{ }^{17}$ The point is, biosemiotics as a pluralistic endeavour is a fact of the definition of the field as well as a historical reality. Now, though we may be in agreement with Barbieri's institutional criticism to some degree, the non-Peircean varieties of biosemiotics contribute a valuable point of view in the integration of alternatives to make sense of meaning-making in biology - the predominant Peircean language and philosophical framework of the field, while solidified, can still grow beyond its own concepts. This will become clearer as we explore what I call post-Peircean biosemiotics.

As biosemiotics has, to a certain extent, dealt with studying its own development (as any discipline should do ${ }^{18}$ ), accounting for different perspectives has had some relevance in both establishing positions and diverging from them. The latter is the case of current code biology, ${ }^{19}$ now a thoroughly non-Peircean enterprise, but other alternatives have also been posited in the description of positions and possibilities, as the ones found in Kull 1999 or Chebanov 1999. The conditions to be met are multidimensional when it comes to representing biosemiotics. In other words, the enterprise, while heavily reliant on Peircean semiotic terminology, offers alternatives that feed from other sources. If anything, non-Peircean biosemiotics, while not in the spotlight, adds a healthy dose of skepticism towards Peircean concepts and a source for criticism and theory change within the whole area of biosemiotics.

\footnotetext{
16 As is the case of zoosemiotics, arguably one of the areas belonging to biosemiotics.

17 We could also include works more removed from the central biosemiotic names such as Juarrero (1999), Barandiaran and Moreno (2008) or Järvilehto (2009) to name only a few. In fact, Donald Favareau's stupendous historiographical account of biosemiotics (Favareau 2008) displays an abundant amount of alternative approaches that have been influenced by and, in turn, influenced biosemiotic developments.

18 Favareau (2015) provides an excellent example of this phenomenon in biosemiotics.

19 Barbieri (2014) reflects the same changes made explicit in 2015 on how the history of biosemiotics took a turn to the Peircean side to an exclusionary degree.
} 


\section{What counts as 'post-Peircean'?}

At the beginning of this paper we asked the question whether it is possible to have a post-Peircean biosemiotics. But what exactly constitutes a post-Peircean framework? Theory change does not always require us to throw the baby out with the bathwater, and despite the concern regarding Peircean gatekeepers at the paradigmatic core of biosemiotics that has been expressed from the camp of code biology, ${ }^{20}$ it is our belief that the discipline can embrace theoretical pluralism ${ }^{21}$ regarding its alleged Peircean core. Being post-anything is usually a declaration of identity and intention: that one proceeds from a certain source, but that one has also decided that certain ties must be severed. Deely's declaration of postmodernity has to do with a rejection of the mainstream conception of postmodernism, declaring Peirce the last of the moderns (Deely 2001: 611), the first to break the precepts of modernity and thus become "postmodern". By the same measure, the post-Peircean should be one inclined to have learned from Peirce, but also capable of saying "no" to him. While some hints have been made about a post-Peircean biosemiotics in Olteanu 2019: 18 and Kull 2019, it remains as a new proposition within the history of biosemiotics, at least formally. ${ }^{22}$ Such a paradigmatic change is not, as may appear at first sight, far-fetched, and in fact there are some common, if not unified, aspects of a critical view of Peirce within biosemiotics beyond the institutional criticism raised by Barbieri, but in the case of Kull 2019, we see a step towards a different sort of heterodoxy in the inclusion of different sign types within the established Peircean taxonomy by introducing the emon as an unaccounted-for element in such semiotics.

A post-Peircean biosemiotics is not necessarily an institutional aim, but rather an opening of semiotic space beyond the continuous adjudication of correctness of Peircean claims. The assertion that most biosemioticians are strongly committed to a Peircean paradigm (Barbieri 2015: 168) and the institutional breakaway of code biology in rejection of this view poses a challenge to biosemiotics as a research framework in general. Now, part of the motivation for such an institutional split lies in the perceived anti-scientific practice of biosemiotics as formulated by the criticism raised by Barbieri, ${ }^{23}$ but there is no

\footnotetext{
20 And, in a more general sense, as an example of a stable paradigm within biosemiotics itself. 21 In the sense of Feyerabend (1999).

22 Olteanu's view of what corresponds to a post-Peircean biosemiotics may, however, differ from my own in what is specifically necessary as a movement beyond Peirce's path, but it remains as one of the first (if not the first) mention of such a movement at all.

23 This claim, as noted earlier, hinges partly on the accusation of language related to intelligent design as employed by biosemioticians.
} 
actual irreconcilability in this separation, as biosemiotics has always appeared as a multidisciplinary endeavour that aims to break through conventional separations in biology, given the lack of a qualitative aspect within mainstream biology (Hoffmeyer 2009). The obstacles faced by code biology are true of at least some area of biosemiotics, and the philosophical spin that has naturally emerged in confronting the issues of meaning in biology should not be considered as a step back into an anti-scientific practice. Instead, the common project that emerged organically remains a more accurate depiction of the potential explanatory power of biosemiotics.

What I am advocating here is not a removal of Peircean metaphysics from biosemiotic parlance, but an acknowledgment of the possibilities that open up when bona fide semiotics deals with other sources. Instead of claiming for a radical scientific post-semiotics, biosemiotics has enough tools at its disposal to incorporate scientific perspectives with its ontological commitments, that is, using meaning as a basal component of research.

Code biology is an attempt to subvert the paradigm of Peircean biosemiotics, as Barbieri (2015: 168) contends, because of the lack of an empirical aspect to it; that is, Peircean concepts taken for granted admit no discovery, given their universalist quality. The metatheoretical stance of code biology, while clear, does not, however, operate on the same level of assumptions about what a semiotic theory does: it neither expects to find and categorize triadic signs nor assumes the existence of sign relations as necessary for meaning-making at a microscopic level, shifting the sense of meaning towards a functionalized status of codes.

In that regard, code biology is a prime example of post-Peircean biosemiotics, and a positive addition to the landscape we currently inhabit. At the same time, the proximity of intentions regarding meaning as relevant for biology is not a chance event, but a continuation of a more general view of the role of meaningmaking for biological processes.

The theoretical pluralism generally advocated by biosemiotics depends, if we consider Barbieri's criticism to be serious, on not limiting the main tenets of semiotics to Peircean concepts as rigid. In my view, a post-Peircean take of the field is not just a justification for keeping a dialogue with those who do not agree with Peirce, but a theoretical stance on possibilities. Pragmatic options that follow a Peirce-Morris interpretation are already productive, ${ }^{24}$ prioritizing a less ontologically committed version of semiotics than in other varieties of biosemiotics. As biosemiotics finds its niche across the natural world, the capacity of the field to dialogue is stretched thin, but bridge theories between the

24 As, for instance, in Maran 2017. 
micro- and macro-levels at which semiosis may be effective (and their respective criticisms) may help the whole field move past issues of scientific credibility and haphazard application of concepts. The possibility of a post-Peircean biosemiotics is effective insofar as we seriously consider the criticism raised by those opposed to a rigid Peircean stance and allow the discussion to flow in both ways. Commitment to one particular area is not what is at stake here. Instead, the possibility of a disciplinary expansion should be seen as a powerful aim for biosemioticians of all different vocations.

\section{References}

Barandiaran, Xavier; Moreno, Álvaro 2008. Adaptivity: From metabolism to behavior. Adaptive Behavior 16(5): 325-344.

Barbieri, Marcello 2008. The code model of semiosis: The first steps toward a scientific biosemiotics. The American Journal of Semiotics 24(1/3):23-37.

- 2009. A short history of biosemiotics. Biosemiotics 2(2): 221-245.

- 2014. From biosemiotics to code biology. Biological Theory 9(2): 239-249.

- 2015. Code Biology: A New Science of Life. Cham: Springer International Publishing.

Beni, Majid Davoody 2019. New mechanistic philosophy and the scientific prospects of code biology. Biosemiotics 12(2): 192-211.

Brier, Søren 2008a. Cybersemiotics: Why Information is Not Enough! Toronto: University of Toronto Press.

- 2008b. The paradigm of Peircean biosemiotics. Signs 2: 20-81.

- 2015. Can biosemiotics be a "science" if its purpose is to be a bridge between the natural, social and human sciences? Progress in Biophysics and Molecular Biology 119(3): 576-587.

- 2017. Biosemiotic anti-humanism: Why culture is an extension of biology and a selforganizing system of meaning. Cybernetics \& Human Knowing 24(2): 93-97.

Champagne, Marc 2009. A note on M. Barbieri's "scientific biosemiotics". The American Journal of Semiotics 25(1/2): 155-161.

- 2013. A necessary condition for proof of abiotic semiosis. Semiotica 197: 283-287.

Chang, Han-liang 2009. Semioticians make strange bedfellows! Or, once again: "Is language a primary modelling system?" Biosemiotics 2(2): 169-179.

Chebanov, Sergei V. 1999. Biohermeneutics and hermeneutics of biology. Semiotica 127(1/4): 215-226.

Cobley, Paul 2016. Cultural Implications of Biosemiotics. (Biosemiotics 15.) Dordrecht: Springer.

Deacon, Terrence 2011. Incomplete Nature: How Mind Emerged from Matter. New York: W. W. Norton \& Company.

Deely, John N. 2001. Four Ages of Understanding: The First Postmodern Survey of Philosophy from Ancient Times to the Turn of the Twenty-First Century. Toronto: University of Toronto Press.

- 2001b. Physiosemiosis in the semiotic spiral: A play of musement. Sign Systems Studies 29(1): 27-47. 
- 2005. The semiotic animal. In: Williamson, Rodney; Sbrocchi, Leonard G.; Deely, John (eds.), Semiotics 2003: "Semiotics and National Identity". New York: Legas, 111-126.

El-Hani, Charbel N.; Queiroz, João; Emmeche, Claus 2009. Genes, Information, and Semiosis. (Tartu Semiotics Library 8.) Tartu: University of Tartu Press.

Emmeche, Claus 2011. Organism and body: The semiotics of emergent levels of life. In: Emmeche, Claus; Kull, Kalevi (eds.), Towards a Semiotic Biology: Life Is the Action of Signs. London: Imperial College Press, 91-112.

Favareau, Donald F. 2008. The evolutionary history of biosemiotics. In: Barbieri, Marcello (ed.), Introduction to Biosemiotics: The New Biological Synthesis. Dordrecht: Springer, 1-67.

- 2015. Why this now? The conceptual and historical rationale behind the development of biosemiotics. Green Letters 19(3): 227-242.

Fernández, Eliseo 2014. Peircean habits and the life of symbols. Chinese Semiotic Studies 7(1): 203-215.

Feyerabend, Paul K. 1999. How to be a good empiricist: A plea for tolerance in matters epistemological. In: Knowledge, Science and Relativism. (Philosophical Papers 3.) Cambridge: Cambridge University Press, 78-103.

Hoffmeyer, Jesper 2008. Biosemiotics: An Examination into the Signs of Life and the Life of Signs. Scranton: University of Scranton Press.

- 2009. Biology is immature biosemiotics. In: Deely, John N.; Sbrocchi, Leonard (eds.), Semiotics 2008: Proceedings of the 33rd Annual Meeting of the Semiotic Society of America. Ottawa: Legas, 927-942.

- 2010. A biosemiotic approach to the question of meaning. Zygon 45(2): 367-390.

Juarrero, Alicia 1999. Dynamics in Action: Intentional Behavior as a Complex System. Cambridge: The MIT Press.

Järvilehto, Timo 2009. The theory of the organism-environment system as a basis of experimental work in psychology. Ecological Psychology 21(2): 112-120.

Kauffman, Stuart 1995. At Home in the Universe: The Search for the Laws of Self-Organization and Complexity. Oxford: Oxford University Press.

Kull, Kalevi 1993. Semiotic paradigm in theoretical biology. In: Kull, Kalevi; Tiivel, Toomas (eds.), Lectures in Theoretical Biology: The Second Stage. Tallinn: Estonian Academy of Sciences, 52-62.

- 1999. Biosemiotics in the twentieth century: A view from biology. Semiotica 127(1/4): 385414.

- 2009a. Biosemiotics: To know, what life knows. Cybernetics and Human Knowing 16(3/4): 81-88.

- 2009b. Vegetative, animal, and cultural semiosis. Cognitive Semiotics 4: 8-27.

- 2018. On the logic of animal umwelten: The animal subjective present and zoosemiotics of choice and learning. In: Marrone, Gianfranco; Mangano, Dario (eds.), Semiotics of Animals in Culture: Zoosemiotics 2.0. (Biosemiotics 17.) Cham: Springer, 135-148.

- 2019. Steps towards the natural meronomy and taxonomy of semiosis: Emon between index and symbol. Sign Systems Studies 47(1/2): 88-104.

Kull, Kalevi; Deacon, Terrence; Emmeche, Claus; Stjernfelt, Frederik; Hoffmeyer, Jesper 2009. Theses on biosemiotics: Prolegomena to a theoretical biology. Biological Theory 4(2): 167173. 
Lidov, David 2019. Genuine triadicity in computation, cognition and consciousness. Chinese Semiotic Studies 15(2): 175-197.

Lotman, Mihhail 2002. Umwelt and semiosphere. Sign Systems Studies 30(1): 33-40.

Maran, Timo 2016. Semiotic modelling of biological mimicry. In: Maran, Timo; Tønnessen, Morten; Rattasepp, Silver (eds.), Animal Umwelten in a Changing World: Zoosemiotic Perspectives. (Tartu Semiotics Library 18.) Tartu: University of Tartu Press, 240-255.

Maran, Timo 2017. On the diversity of environmental signs: A typological approach. Biosemiotics 10(3): 355-368.

Markoš, Anton 2002. Readers of the Book of Life: Contextualizing Developmental Evolutionary Biology. Oxford: Oxford University Press.

Olteanu, Alin 2019. Multiculturalism as Multimodal Communication: A Semiotic Perspective. Cham: Springer.

Pattee, Howard H. 2008. The necessity of biosemiotics: Matter-symbol complementarity. In: Barbieri, Marcello (ed.), Introduction to Biosemiotics: The New Biological Synthesis. Dordrecht: Springer, 115-132.

Petrov, Petre 2013. Mixing signs and bones: John Deely's case for global semiotics. Sign Systems Studies 41(4): 404-423.

Rodríguez Higuera, Claudio Julio 2019. Some challenges to the evolutionary status of semiosis. Biosemiotics 12(3): 405-421.

Rodríguez Higuera, Claudio J.; Kull, Kalevi 2017. The biosemiotic glossary project: The semiotic threshold. Biosemiotics 10(1): 109-126.

Romanini, Vinicius; Fernández, Eliseo 2014. Peirce and Biosemiotics: A Guess at the Riddle of Life. (Biosemiotics 11.) Dordrecht: Springer.

Rosen, Robert 1991. Life Itself: A Comprehensive Inquiry into the Nature, Origin, and Fabrication of Life. New York: Columbia University Press.

Sharov, Aleksei A. 2010. Functional information: Towards synthesis of biosemiotics and cybernetics. Entropy 12(5): 1050-1070.

- 2016. Evolution of natural agents: Preservation, advance, and emergence of functional information. Biosemiotics 9(1): 103-120.

Stjernfelt, Frederik 2007. Diagrammatology: An Investigation on the Borderlines of Phenomenology, Ontology, and Semiotics. Dordrecht: Springer.

- 2012. The evolution of semiotic self-control. In: Schilhab, Theresa; Stjernfelt, Frederik; Deacon, Terrence (eds.), The Symbolic Species Evolved. (Biosemiotics 6.) Dordrecht: Springer, 39-63.

Vega, Federico 2018. A critique of Barbieri's code biology through Rosen's relational biology: Reconciling Barbieri’s biosemiotics with Peircean biosemiotics. Biological Theory 13: 261279.

Vehkavaara, Tommi 2003. Natural self-interest, interactive representation, and the emergence of objects and umwelt. Sign Systems Studies 31(2): 547-586.

- 2005. Limitations on applying Peircean semeiotic: Biosemiotics as applied objective ethics and esthetics rather than semeiotic. Journal of Biosemiotics 1(1): 269-308.

- 2007. From the logic of science to the logic of the living: The relevance of Charles Peirce to biosemiotics. In: Barbieri, Marcello (ed.), Introduction to Bioemiotics: The New Biological Synthesis. Dordrecht: Springer, 257-282. 


\section{Все кажется тут устроено: мыслимость пост-пирсовской биосемиотики}

Изменение теории - это медленный и мучительный процесс. Проблемы, связанные с тем, как мы передаем идеи и как они воспринимаются нашими коллегами, становятся катализатором перемен в нашем понимании возможностей самой дисциплины. Некоторые части семиотики, и в особенности биосемиотики, попали под испытующий взгляд критиков из-за чрезмерной приверженности философии Пирса, но в то же время и вклад философии Пирса практически невозможно сбрасывать со счетов. Волны этой ситуации вполне заметны при появлении кодовой биологии как постсемиотической исследовательской программы. Тем не менее, существует некоторое равновесие между теми, кто не вкладывает столько в концепции Пирса, и теми, кто не может зачать семиотику без этого. В этой статье задается вопрос, возможна ли вообще биосемиотика после Пирса в смысле признания вклада Пирса в эту область и в то же время принимая во внимание критические замечания тех, кто скептически относится к введению пирсовской семиотики. Хотя ответ, скорее всего, положительный, он зависит от того, на основе какой теории мы строим наше понятие значения и как оно может переноситься в другие области семиотики, на которые биосемиотики могут претендовать. Способность обсуждать потенциальные теоретические различия между семиотиками разных областей будет иметь решающее значение для здоровья дисциплины, так как разрыв между теориями становится все более глубоким.

\section{Kõik tundub siin nii paigas olevat: Peirce'i-järgse biosemiootika mõeldavus}

Teooria muutumine on aeglane ja piinarikas protsess. Probleemidest, mis on seotud sellega, kuidas me ideid vahendame ning kuidas meie kaaslased neid ideid vastu võtavad, saavad muutuste katalüsaatorid selles, kuidas me ise tajume ning lubame seda, mida mingi distsipliin teha võib. Mõned semiootika, ning eriti biosemiootika, osad on sattunud kriitilise uurimise objektiks seetõttu, et neis on tugevasti pühendutud peirce'ilikule filosoofiale, kuid samas on Peirce'i filosoofia panuste arvestamata jätmine praktiliselt võimatu. Selle olukorra põhjustatud lainetust on märgata koodibioloogia kui postsemiootilise uurimisprogrammi esilekerkimises. Kuid siiski valitseb üldine tasakaal nende vahel, kes ei hinda peirce'ilikke mõisteid nii kõrgelt, ja nende, kes ei suuda semiootikat ilma nendeta ette kujutada.

Käesolevas artiklis küsitakse, kas biosemiootika pärast Peirce’i on ülepea võimalik tähenduses, et tunnustatakse Peirce'i panust sellesse valdkonda, võttes samas arvesse ka kriitikat, mis lähtub neilt, kes on skeptilised peirce'iliku semiootika implikatsioonide suhtes. Kuigi vastus on üldjoontes jaatav, oleneb see sellest, millisele taustale meie tähenduse mõiste toetub, ning kuidas see võib valguda teistesse semiootikavaldkondadesse, kus biosemiootikal võib midagi mängus olla. Suutlikkusel arutada potentsiaalseid teoreetilisi eristusi kogu semiootikas, võimaldades samas kommunikatsiooni valdkondade vahel, mis on sellesse eristamisesse kaasatud, on otsustav tähendus distsipliini tervises, kui teooriate vaheline lõhe on süvenemas. 